\title{
Regulation of glucokinase in pancreatic islets by prolactin: a mechanism for increasing glucose-stimulated insulin secretion during pregnancy
}

\author{
Anthony J Weinhaus, Laurence E Stout ${ }^{\mathbf{1}}$, Nicholas V Bhagroo ${ }^{\mathbf{1}}$, T Clark Brelje ${ }^{\mathbf{1}}$ and Robert L Sorenson ${ }^{\mathbf{1}}$ \\ Department of Integrative Biology and Physiology, University of Minnesota, 6-125 Jackson Hall, 321 Church St SE, Minneapolis, Minnesota 55455-0303, USA \\ ${ }^{1}$ Department of Genetics, Cell Biology and Development, University of Minnesota, Minneapolis, Minnesota, USA \\ (Requests for offprints should be addressed to R L Sorenson; Email: soren001@umn.edu)
}

\begin{abstract}
Glucokinase activity is increased in pancreatic islets during pregnancy and in vitro by prolactin (PRL). The underlying mechanisms that lead to increased glucokinase have not been resolved. Since glucose itself regulates glucokinase activity in $\beta$-cells, it was unclear whether the lactogen effects are direct or occur through changes in glucose metabolism. To clarify the roles of glucose metabolism in this process, we examined the interactions between glucose and PRL on glucose metabolism, insulin secretion, and glucokinase expression in insulin 1 (INS-1) cells and rat islets. Although the PRLinduced changes were more pronounced after culture at higher glucose concentrations, an increase in glucose metabolism, insulin secretion, and glucokinase expression occurred even in the absence of glucose. The presence of comparable levels of insulin secretion at similar rates of glucose metabolism from both control and PRL-treated
\end{abstract}

INS-1 cells suggests the PRL-induced increase in glucose metabolism is responsible for the increase in insulin secretion. Similarly, increases in other known PRL responsive genes (e.g. the PRL receptor, glucose transporter-2, and insulin) were also detected after culture without glucose. We show that the upstream glucokinase promoter contains multiple STAT5 binding sequences with increased binding in response to PRL. Corresponding increases in glucokinase mRNA and protein synthesis were also detected. This suggests the PRLinduced increase in glucokinase mRNA and its translation are sufficient to account for the elevated glucokinase activity in $\beta$-cells with lactogens. Importantly, the increase in islet glucokinase observed with PRL is in line with that observed in islets during pregnancy.

Journal of Endocrinology (2007) 193, 367-381

\section{Introduction}

To accommodate the increased demand for insulin during pregnancy, pancreatic islets of Langerhans undergo structural and functional changes leading to increased insulin release under normal glucose homeostasis (Parsons et al. 1992, Sorenson \& Brelje 1997). The most important changes are lowering of the threshold for glucose-stimulated insulin secretion and expansion of islet mass (Parsons et al. 1992). The primary factors responsible for these adaptive changes are the lactogenic hormones placental lactogen and/or prolactin (PRL; Brelje et al. 1993, 2004). We have shown these hormones induce, both in vitro and in vivo, similar changes in islets as those observed during pregnancy (Sorenson \& Brelje 1997, 2001).

Although the effects of lactogens on islets have been well characterized, the cellular mechanisms by which lactogens induce these changes are less well known. Lactogens exert their biological effects mainly thorough the binding to the PRL receptor (PRL-r) and activating the JAK2/STAT5 pathway (Sorenson \& Stout 1995, Galsgaard et al. 1999, Brelje et al. 2002, 2004). Phosphorylated STAT5 proteins dimerize, translocate to the nucleus, and bind to palindromic $\gamma$ interferon activating sequences (GAS) in the promoters of target genes and modulate gene transcription (Ihle 1996). The importance of STAT5 activation in $\beta$-cells was shown by the similarity of lactogen's effects to the expression of a constitutively active STAT 5 and their inhibition by expression of a dominant negative STAT5 (Friedrichsen et al. 2001). The PRL-r (Galsgaard et al. 1999), insulin (Galsgaard et al. 1996), and cyclin D2 (Friedrichsen et al. 2003) promoters have been shown to contain functional STAT5 binding sites in $\beta$-cells.

The cellular mechanisms by which lactogens lower the threshold of glucose-stimulated insulin secretion and elevate insulin release are less clear. We have shown that islets from pregnant rats or cultured with PRL have increased glucose metabolism (Weinhaus et al. 1996). In addition, the elevated insulin secretion can be accounted for solely in terms of their increased rates of glucose oxidation (Weinhaus et al. 1996, 1998). In $\beta$-cells, the rate-limiting step in glucose metabolism is the phosphorylation of glucose by the enzyme glucokinase 
(Magnuson \& Matschinsky 2004). Accordingly, glucokinase activity and protein levels are increased in lactogen treated islets and in islets during pregnancy (Weinhaus et al. 1996). Even small changes in glucokinase expression or activity have very substantial effects on insulin secretion, and in particular, the threshold of glucose-stimulated insulin secretion (Wang \& Iynedjian 1997, Davis et al. 1999, Magnuson \& Matschinsky 2004). For example, the decrease in threshold from $5 \cdot 5$ to $3 \cdot 3 \mathrm{mM}$ glucose during pregnancy (Parsons et al. 1992), only requires a $60 \%$ increase in glucokinase activity (Weinhaus et al. 1996). This suggests that an increase in glucokinase activity is a key event in the lactogen-induced elevation of insulin secretion during pregnancy.

Glucokinase activity is regulated at both transcriptional and post-translational levels in $\beta$-cells (Iynedjian 2004, Magnuson \& Matschinsky 2004). The transcription of glucokinase has been shown to be affected by a variety of factors, including insulin, cAMP, biotin, and retinoic acid. Although glucose does not alter the levels of glucokinase mRNA in $\beta$-cells, glucokinase activity and protein levels are increased suggesting an effect at the translational or protein stability levels (Liang et al. 1992, Marie et al. 1993, Chen et al. 1994, Gasa et al. 2000). Since, most studies are done in culture media that contains glucose, it is unclear whether the effects of lactogens are exerted directly or through other changes in metabolism. A direct mechanism could be the transcriptional regulation of glucokinase by STAT5 as has been demonstrated for other target genes in $\beta$-cells (Galsgaard et al. 1996, 1999, Friedrichsen et al. 2003). Alternately, an indirect mechanism dependent on other changes in glucose metabolism may occur. We have shown that PRL induces proportional increases in glucose metabolism, cAMP levels, and insulin secretion (Weinhaus et al. 1998, Shao et al. 2004). This elevation in cAMP may increase glucokinase transcription similar to the proportional increases in glucokinase activity and mRNA in islets cultured with cAMP (Fernandez-Mejia et al. 2001). Similar to the effects of glucose itself, PRL could also increase glucokinase activity and protein levels through an effect at the translational or protein stability levels.

To clarify the roles of glucose metabolism in lactogen's action, we examined the interactions between PRL and glucose in the regulation of glucose metabolism, insulin secretion, and glucokinase expression in $\beta$-cells. These experiments were done in both transformed and normal $\beta$-cells. The presence of STAT5 binding motifs in the upstream promoter of the glucokinase gene utilized in $\beta$-cells was investigated. To confirm the transcriptional regulation of glucokinase expression by PRL, the levels of glucokinase mRNA and its rate of biosynthesis and degradation were also examined.

\section{Materials and Methods}

\section{Hormones}

The rat PRL (NIDDK-rPRL-B-8-SIAFP) was provided by the National Hormone and Pituitary Program (Dr A F
Parlow, Harbor-UCLA Medical Center, Torrance, CA, USA). PRL was used at $200 \mathrm{ng} / \mathrm{ml}$ with insulin 1 (INS-1) cells and $500 \mathrm{ng} / \mathrm{ml}$ with islets - concentrations that induce maximal activation of STAT5 (Brelje et al. 2004).

\section{Ins- 1 cells}

The rat insulinoma INS-1 was provided by Claes Wollheim (University of Geneva, Geneva, Switzerland) and grown as previously described (Stout et al. 1997, Brelje et al. 2004). Experiments were done in a serum-free medium consisting of RPMI 1640 (Stout et al. 1997) with $10 \mathrm{mM}$ glucose supplemented to give a final concentration of $6 \mathrm{mM}$ glutamine, $0 \cdot 1 \%$ human serum albumin, $10 \mathrm{mM}$ HEPES, $10 \mu \mathrm{g} / \mathrm{ml}$ human transferrin, $0 \cdot 1 \mathrm{nM}$ triiodothyronine, $50 \mu \mathrm{M}$ ethanolamine, $50 \mu \mathrm{M}$ phosphoethanolamine, and $1 \%$ antibiotic-antimycotic. To prevent the reduction in the viability in the absence of glucose (unpublished observation), we increased the glutamine concentration in all culture media. Growing INS-1 cells at high densities can reduce the expression of proteins related to their $\beta$-cell phenotype (Stout et al. 1997). Therefore, the INS-1 cells were plated at $15-20 \%$ confluence and were never more than $70-80 \%$ confluence after a 48 h experiment.

\section{Rat islets}

Islets were isolated from 3- to 5-day-old Sprague-Dawley rats (Sasco, Omaha, NE, USA) by a non-enzymatic culture method (Hegre et al. 1983). After this initial culture, groups of 30 islets were cultured free-floating in 24-well plates in $2 \mathrm{ml}$ RPMI-1640 with $10 \mathrm{mM}$ glucose supplemented to give a final concentration of $6 \mathrm{mM}$ glutamine, $10 \mathrm{mM}$ HEPES, $1 \%$ horse serum, and $1 \%$ antibiotic-antimycotic at $37^{\circ} \mathrm{C}$ in a humidified atmosphere of $5 \% \mathrm{CO}_{2}$ in air. All procedures were approved by the institutional animal care and use committee at the University of Minnesota.

\section{Insulin secretion and metabolic activity}

Glucose-stimulated insulin secretion was examined by preincubating in Krebs balanced salt solution containing $2 \mathrm{mM}$ glucose for $1 \mathrm{~h}$ before stimulation with $2-10 \mathrm{mM}$ glucose (with $500 \mu \mathrm{M}$ IBMX) for $1 \mathrm{~h}$ (Weinhaus et al. 1998). Insulin secretion was normalized based on the total protein content of the INS-1 cells or islet number. Metabolic activity was monitored by following the reduction of a tetrazolium compound (MTS; Promega) to its formazan product by measuring its absorbance at $490 \mathrm{~nm}$ (Segu et al. 1998).

\section{Western blots}

Western blots were prepared from INS-1 cells and islets as previously described (Brelje et al. 2004). The following primary antibodies were used at a 1:2000 dilution: sheep antiglucokinase (provided by Dr Mark Magnuson, Vanderbilt University, Nashville, TN, USA), rabbit anti-PRL-r (Brelje 
et al. 2002), rabbit anti-glucose transporter 2(Glut-2; provided by $\mathrm{Dr}$ Bernard Thorens, Institute of Pharmacology and Toxicology, Lausanne, Switzerland), guinea pig anti-insulin, mouse anti- $\alpha$-actin (Sigma), and rabbit anti-STAT5a and STAT5b (Santa Cruz Biotechnology, Santa Cruz, CA, USA). Bound antibodies were detected using a 1:30 000 dilution of alkaline phosphatase-conjugated donkey secondary antibodies (Jackson ImmunoResearch Laboratories, West Grove, PA, USA) and the chemiluminescent substrate CSPD (Tropix, Bedford, MA, USA). A Bio-Rad GS-700 (Bio-Rad) was used for quantitative densitometry with the volume density of bands calculated as $\mathrm{OD} \times \mathrm{mm}^{2}$ after background correction.

\section{Southwestern blots}

Nuclear extracts were prepared from INS-1 cells exposed to $250 \mathrm{ng} / \mathrm{ml}$ PRL for $30 \mathrm{~min}$ as previously described (Galsgaard et al. 1999). The oligonucleotide probes were prepared from 17-base DNA sequences (Integrated DNA Technologies, Coraville, IA, USA) and labeled with digoxygenin (DIGddUTP, Boehringer-Mannheim). After western blot analysis using a rabbit STAT5b antibody, the membranes were stripped of bound antibodies with $6 \mathrm{M}$ guanidine hydrochloride before incubation with the oligonucleotide probes and a 500-fold excess of sonicated salmon sperm DNA (Sigma) for $1 \mathrm{~h}$ at room temperature. Binding was visualized using sheep alkaline phosphatase-conjugated anti-digoxygenin Fab fragments (Boehringer-Mannheim) and the chemiluminescent substrate CSPD (Applied Biosystems, Foster City, CA, USA).

\section{Electromobility shift assays}

Nuclear extracts were prepared from INS-1 cells exposed to $250 \mathrm{ng} / \mathrm{ml}$ PRL for $30 \mathrm{~min}$ as previously described (Galsgaard et al. 1999). Oligonucleotides containing GAS motifs from the rat upstream glucokinase, PRL-r, and INS-1 promoters were obtained from Invitrogen. The double-stranded oligonucleotide probes were radiolabeled with $\left[\alpha-{ }^{32} \mathrm{P}\right] \mathrm{dATP}$ (NEN, Boston, MA, USA) using DNA polymerase (Klenow fragment; Sigma). Binding was performed in $20 \mu \mathrm{l}$ volume with $20 \mathrm{fmol}$ radiolabeled probe, $10 \mu \mathrm{g}$ nuclear extract, $20 \mathrm{mM}$ HEPES $(\mathrm{pH}$ 7.9); $50 \mathrm{mM} \mathrm{NaCl}, 1 \mathrm{mM} \mathrm{MgCl} 2,1 \mathrm{mM}$ EDTA, $1 \mathrm{mM}$ dithiothreitol, $1 \mathrm{mM}$ phenylmethylsulfonylfluoride, $20 \mu \mathrm{g} / \mathrm{ml}$ BSA, $13 \%$ glycerol, $1 \mathrm{mM}$ spermadine, and $0 \cdot 1 \mu \mathrm{g} / \mu \mathrm{l}$ Poly $(\mathrm{dI}-$ dC). After incubation for $30 \mathrm{~min}$ at $30^{\circ} \mathrm{C}$, the products were separated by electrophoresis on $3 \%$ polyacrylamide gels containing $3 \cdot 2 \%$ glycerol and $0.5 \times$ TBE $(44 \mathrm{mM}$ Tris $-\mathrm{HCl}$, $44 \mathrm{mM}$ boric acid, and 1.0 mM EDTA, pH 7.9). For supershift studies, the nuclear extracts were incubated for $1 \mathrm{~h}$ with rabbit STAT5a or STAT5b antibodies.

\section{Quantitative RT-PCR}

Total RNA was prepared from INS-1 cells and isolated islets using TRIzol reagent (Invitrogen) according to the manufacturer's protocol. For islets, $50 \mu \mathrm{g} / \mathrm{ml}$ blue mussel glycogen (Sigma) was also used as a co-precipitant. RNA concentrations were determined spectrophotometrically using the Warburg-Christian equation. cDNA was synthesized using oligo(dT $)_{20}$ as a primer and reverse transcribed with SuperScript III (Invitrogen) according to the manufacturer's protocol. RT-PCR was performed by monitoring in real time the increase in fluorescence using the FastStart DNA Master SYBR Green I kit and the LightCycler detection system (Roche Applied Science). Primers from the distal end of exon 10 of the rat glucokinase gene (5'-ACCTGAGTGTTGGAGATGATTC- $3^{\prime}$ and $5^{\prime}$-CCGAGTGGCTTACAGTTCTG- $3^{\prime}$ ) were used. Specificity of the primer pair was confirmed by melting curve analysis and agarose gel electrophoresis of PCR products. For comparison of transcript levels between samples, relative quantification of steady-state mRNA levels across multiple samples was obtained. A standard curve from serial dilutions of a reference RNA sample was established and used to calculate the relative abundance of glucokinase mRNA for each preparation. All PCRs were performed in triplicate. Negative and positive controls were water and rat liver genomic DNA respectively.

\section{Biosynthetic labeling}

The synthesis and degradation of glucokinase was measured in INS-1 using the methods of Gremlich et al. (1997). The cells were pre-incubated for $30 \mathrm{~min}$ in Krebs-Ringer bicarbonate buffer supplemented with amino acids depleted of methionine and $10 \%$ dialyzed fetal calf serum before the addition of $80 \mu \mathrm{Ci} / \mathrm{ml}\left[{ }^{35} \mathrm{~S}\right]$ methionine $\left(\operatorname{Tran}{ }^{35} \mathrm{~S}-\right.$ Label; MP Biomedicals, Irvine, CA, USA) for $10 \mathrm{~min}$ at $37^{\circ} \mathrm{C}$. The incorporation of label was determined by immunoprecipitation with a 1:80 dilution of the glucokinase antibody and protein G-sepharose beads (Sigma) followed by separation on $7 \cdot 5 \%$ polyacrilamide gels with $0 \cdot 1 \%$ SDS. The gels were treated with NAMP100 amplify fluorographic reagent (Amersham), dried, and exposed with intensifying screens to Hyperfilm MP (Amersham) for $48 \mathrm{~h}$ at $-70{ }^{\circ} \mathrm{C}$. Degradation was determined by pulse-labeling with $\left[{ }^{35} \mathrm{~S}\right]$ methionine for $3 \mathrm{~h}$ and chasing for an additional 6, 12 and $24 \mathrm{~h}$.

\section{Statistical analysis}

All values are expressed as mean \pm S.E.M. of $n$ separate experiments. Student's $t$ test or ANOVA with NewmanKeuls post-test was used for comparisons with differences of $P<0 \cdot 05$ considered significant.

\section{Results}

Glucose dependence of PRL's effects on $\beta$-cells

Although glucokinase is increased in islets cultured at high glucose with PRL (Weinhaus et al. 1996), the glucose 
dependence of this effect of PRL on $\beta$-cell function was unknown. INS-1 cells were cultured for $48 \mathrm{~h}$ in $0-10 \mathrm{mM}$ glucose with or without $200 \mathrm{ng} / \mathrm{ml} \mathrm{PRL}$, before stimulation with $8 \cdot 2 \mathrm{mM}$ glucose for $1 \mathrm{~h}$. Prior culture in increasing glucose concentrations enhanced both glucose metabolism and insulin secretion (Fig. 1A and B). PRL further increased these responses compared with glucose alone (Fig. 1A and B, $P<0 \cdot 05$ ). A similar pattern of increases in glucokinase expression with PRL at all glucose concentrations was observed (Fig. 1C, $P<0 \cdot 05$ ). Importantly, PRL still induced a $24 \pm 4 \%$ increase in glucokinase expression in the absence of glucose. This demonstrates that PRL can regulate glucokinase expression in transformed $\beta$-cells in the presence or absence of glucose.

Since modifications in metabolism occur in transformed tumor cells, similar experiments were done with normal $\beta$-ells. Rat islets were cultured for $48 \mathrm{~h}$ in $0-10 \mathrm{mM}$ glucose with or without $500 \mathrm{ng} / \mathrm{ml} \mathrm{PRL}$, before stimulation with $8.2 \mathrm{mM}$ glucose for $1 \mathrm{~h}$. PRL induced increases in insulin secretion and glucokinase at all glucose concentrations including islets cultured in the absence of glucose (Fig. 2, $P<0 \cdot 05)$. PRL increased glucokinase $\sim 70 \%$ in islets cultured in 0,2 , or $4 \mathrm{mM}$ glucose. In islets cultured in glucose concentrations above the threshold for glucose stimulated insulin secretion (i.e. $5.0 \mathrm{mM}$ ), the effect of PRL was twice as large or an $\sim 140 \%$ increase in glucokinase in comparison to the control islets. This demonstrates that PRL can increase glucokinase expression in normal $\beta$-cells at glucose concentrations below the threshold for glucose-stimulated insulin secretion, including in the absence of glucose. In addition, this effect can be further enhanced by culturing the islets at stimulatory glucose concentrations. This suggests that there is a glucose-dependent and a glucose-independent component to the regulation of glucokinase by PRL in normal $\beta$-cells.

\section{$P R L$ enhances $\beta$-cell function in the absence of glucose}

Since PRL can increase glucokinase levels in $\beta$-cells through a glucose-independent mechanism, it was of interest to determine the effect of PRL on other aspects of $\beta$-cell function in the absence of glucose including proteins (insulin and PRL-r) known to be influenced by PRL through the JAK/STAT5 pathway. INS-1 cells were cultured for $48 \mathrm{~h}$ without glucose and with or without $200 \mathrm{ng} / \mathrm{ml}$ PRL before stimulation with $2-10 \mathrm{mM}$ glucose for $1 \mathrm{~h}$. In cells cultured with PRL, glucose metabolism was increased at all glucose concentrations (Fig .3A, $P<0 \cdot 05$ ). Similarly, PRL treatment increased insulin secretion at all glucose concentrations (Fig. 3A, $P<0 \cdot 05$ ). When glucose metabolism was plotted against insulin secretion (Fig. 3A), there was a single linear relationship for both groups $\left(r^{2}=0.95\right)$ suggesting the PRLinduced increase in insulin secretion was due to an elevation in glucose metabolism. The expression of glucokinase and known PRL responsive proteins (insulin and PRL-r) in $\beta$-cells was also examined. In the absence of glucose, PRL induced significant increases in glucokinase $(35 \pm 9 \%)$, insulin $(46 \pm 10 \%)$, and PRL-r ( $84 \pm 15 \%$; Fig. 3B, $P<0 \cdot 05)$.
Similar experiments were done in rat islets to confirm the results obtained with INS-1 cells. Isolated rat islets were cultured for $48 \mathrm{~h}$ without glucose and with or without $500 \mathrm{ng} / \mathrm{ml}$ PRL before stimulation with $4-8 \mathrm{mM}$ glucose for $1 \mathrm{~h}$. PRL treatment increased insulin secretion at all glucose concentrations (Fig. 4A). In the absence of glucose, PRL induced significant increases in glucokinase (68土19\%), insulin $(60 \pm 18 \%)$, and PRL-r $(75 \pm 21 \%$; Fig. 4B; $P<0 \cdot 05)$. These experiments show that PRL can increase glucokinase as well as two well documented PRL responsive proteins independent of the presence of glucose. Because of the known regulatory influences of PRL on insulin and PRL-r through a JAK/STAT5 mechanism it suggests that PRL may similarly regulate glucokinase.

PRL increases nuclear protein binding to GAS motifs from the upstream glucokinase promoter

Previous studies have shown that PRL-r activate gene transcription through highly conserved STAT5 binding elements similar to the palindromic GAS, TTCNNNGAA (Ihle 1996). The rat upstream glucokinase promoter contains four GAS-related elements (GRE) between -2000 and -1600 of transcription initiation (Fig. 5A). Two of these, GRE-A and GRE-D, are similar to the consensus GAS motif required for optimal binding of STAT5 (Ehret et al. 2001).

Southwestern blots were used to examine the binding of GRE-A to nuclear extracts from INS-1 cells. Probing with a STAT5b antibody showed bands at 95 and $97 \mathrm{kDa}$ with the later band only detected with PRL (Fig. 5B). These bands represent STAT5b in its non-tyrosine phosphorylated and activated tyrosine-phosphorylated forms respectively (Stout et al. 1997, Brelje et al. 2002). Reprobing with a labeled oligonucleotide containing GRE-A showed a single band in the same location as the tyrosine-phosphorylated STAT5b induced by PRL (Fig. 5B). This binding was abolished by mutation of the GAS motif. Similarly, probes containing GAS motifs from the rat PRL-r (Galsgaard et al. 1999) and INS-1 (Galsgaard et al. 1996) promoters produced bands in the same location (Fig. 5B).

Initial electrophoretic mobility shift assays (EMSA) were done with nuclear extracts from INS-1 cells and oligonucleotide probes containing GRE-A or GRE-D. For comparison, probes containing the GAS motifs from the rat PRL-r and INS-1 promoters were also examined. Neither GRE-A or GRE-D formed complexes with the nuclear proteins from PRL-stimulated INS-1 cells (data not shown). The prominent bands with the PRL-r and INS-1 probes (Fig. 6, $P<0 \cdot 001)$ suggests that GRE-A and GRE-D either do not bind nuclear proteins or may form complexes insufficiently stable to withstand electrophoresis.

Since the transcriptional activation of several STAT5responsive genes requires multiple GAS motifs (Verdier et al. 1998, John et al. 1999, Soldaini et al. 2000), we examined whether sequences adjacent to GRE-A and GRE-D affect binding. Near each is another GAS-related motif that are 
A

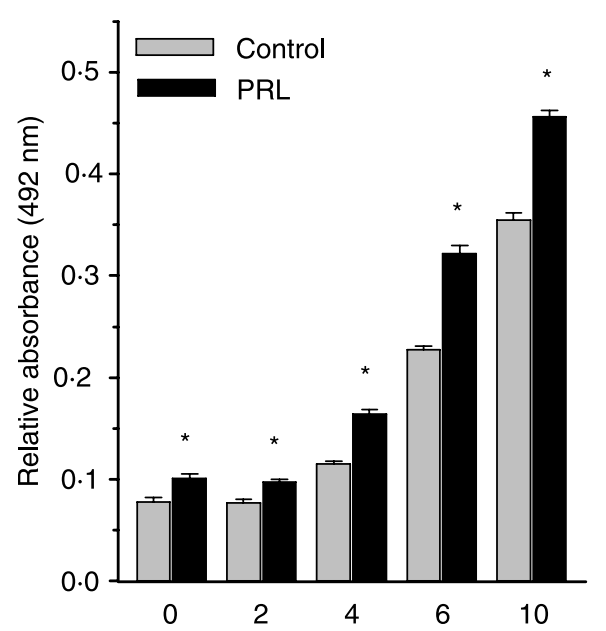

B

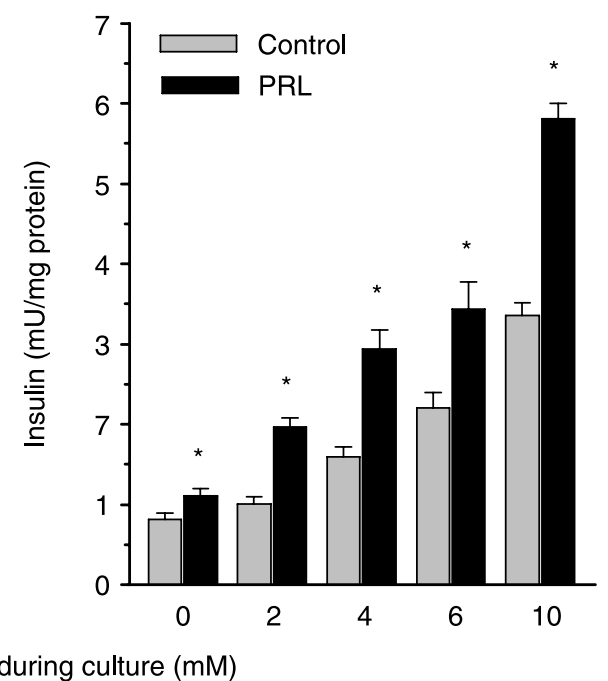

C

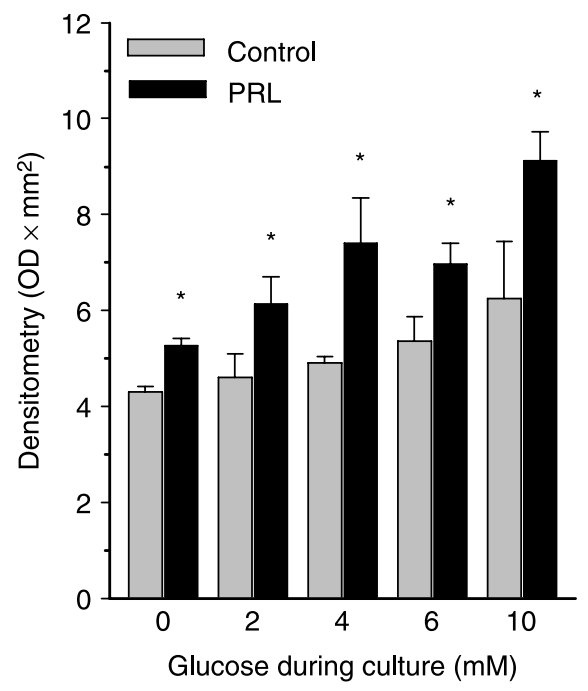

PRL-induced increase

$24 \% \quad 33 \% \quad 51 \% \quad 30 \% \quad 46 \%$

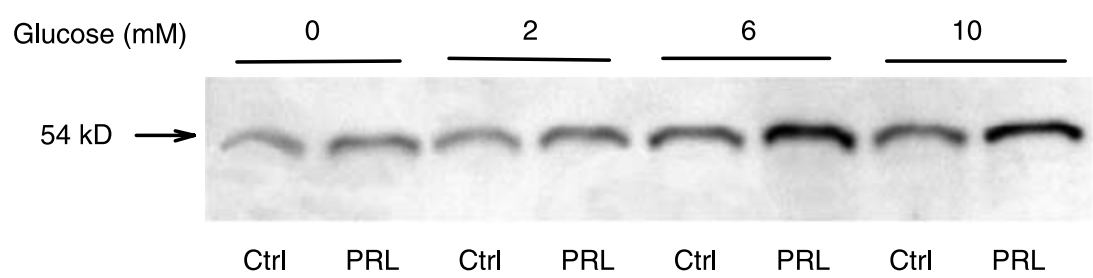

Figure 1 PRL increases glucose metabolism, insulin secretion, and glucokinase expression in INS-1 cells. INS-1 cells were cultured for $48 \mathrm{~h}$ in $0-10 \mathrm{mM}$ glucose before stimulation with $8 \cdot 2 \mathrm{mM}$ glucose for $1 \mathrm{~h}$. (A) Glucose metabolism was progressively higher after prior culture with increasing concentrations of glucose. PRL further increased it whether in the presence or absence of glucose $\left({ }^{*} P<0 \cdot 05, n=9\right)$. (B) A similar pattern was observed on insulin secretion $\left({ }^{*} P<0 \cdot 05, n=9\right)$. (C) PRL also increased the protein levels of glucokinase whether in the absence or presence of glucose $\left({ }^{*} P<0 \cdot 05, n=6\right)$. A representative western blot is shown. 
A

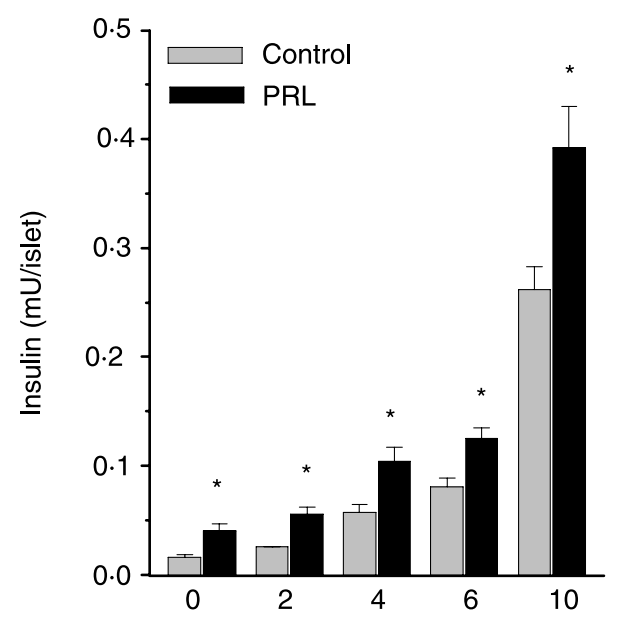

B

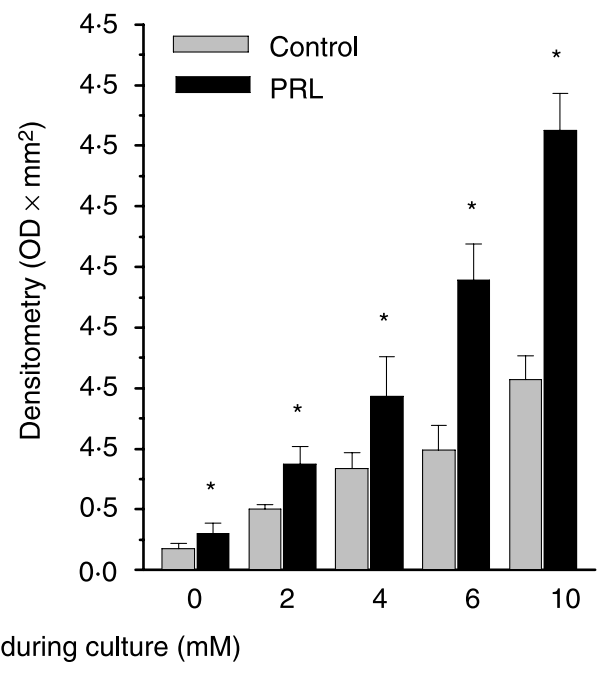

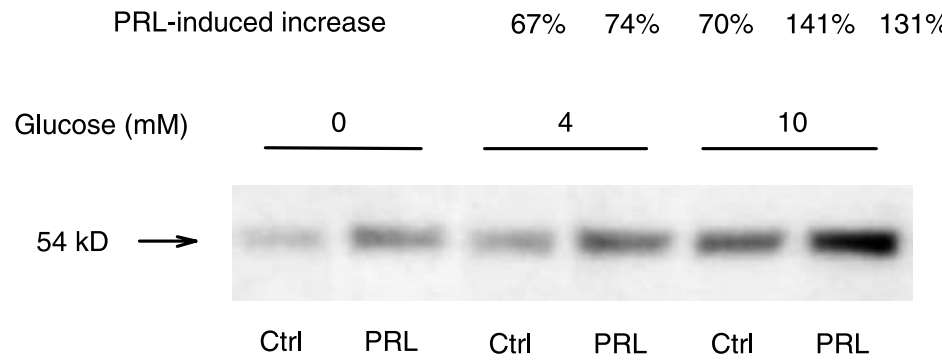

Figure $2 \mathrm{PRL}$ increases insulin secretion and glucokinase expression in rat islets. Islets were cultured for $48 \mathrm{~h}$ in 0-10 mM glucose before stimulation with $8.2 \mathrm{mM}$ glucose for $1 \mathrm{~h}$. (A) Insulin secretion was higher after prior culture with PRL whether in the absence or presence of glucose $\left({ }^{*} P<0 \cdot 05, n=6\right)$. (B) PRL also induced similar increases in the protein levels of glucokinase whether in the absence or presence of glucose $\left({ }^{*} P<0 \cdot 05\right.$, $n=6)$. A representative western blot is shown.

unlikely to bind STAT5 by themselves because the spacing between their palindrome half-sites is less than the required three nucleotides (GRE-B and GRE-C; Fig. 5A). However, each contains a palindrome half-site located seven nucleotides from a consensus GAS motif that can increase the affinity of STAT5 binding in tandem motifs (Verdier et al. 1998). EMSAs were repeated with the tandem probes containing GRE-A and GRE-B (GK-AB) or GRE-C and GRE-D (GK-CD). Unlike the individual probes, these tandem probes formed complexes that increased with PRL (Fig. 6, $P<$ 0.001). Binding with nuclear extracts from control cells was unexpected considering they contain no activated STAT5. However, multiple complexes also occur with probes containing the GAS motifs from the rat INS-1 (Fleenor \& Freemark 2001) and the hepatocyte-specific down stream glucokinase (Sawka-Verhelle et al. 2000) promoters. This control level of binding apparently does not require the GREs because it occurs to a similar extent with the tandem probe containing mutated GRE-A and GRE-B (GK-ABmut; Fig. 6). This PRL-induced complex appeared to be specific because it disappeared with excess of unlabeled GK-AB
(Fig. 6). A similar decrease with an excess of unlabeled GK-CD suggests both probes are binding the same proteins (Fig. 7A). In addition, competition with an unlabeled probe containing the GAS motif from the PRL-r promoter suggests STAT5 is one of these proteins (Fig. 7A).

\section{PRL promotes STAT5 binding to a tandem GRE}

To determine whether STAT5 is bound to the tandem probe GK-AB, EMSA was performed with nuclear extracts from PRL-induced INS-1 cells pre-incubated with antibodies that recognize STAT5a or STAT5b. The bound complex was partly supershifted by a STAT5a antibody and completely supershifted by a STAT5b antibody (Fig. 7B). These results indicate that STAT $5 \mathrm{a} / \mathrm{b}$ binds to the probe.

\section{$P R L$ increases glucokinase $m R N A$}

PRL-induced binding of STAT5 to GAS motifs in the upstream glucokinase gene promoter should increase glucokinase mRNA in $\beta$-cells. A prior study was unable to detect 


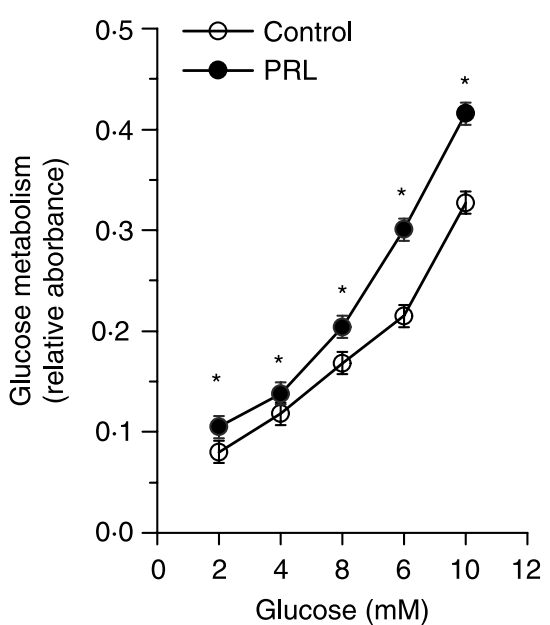

Glucose (mM)
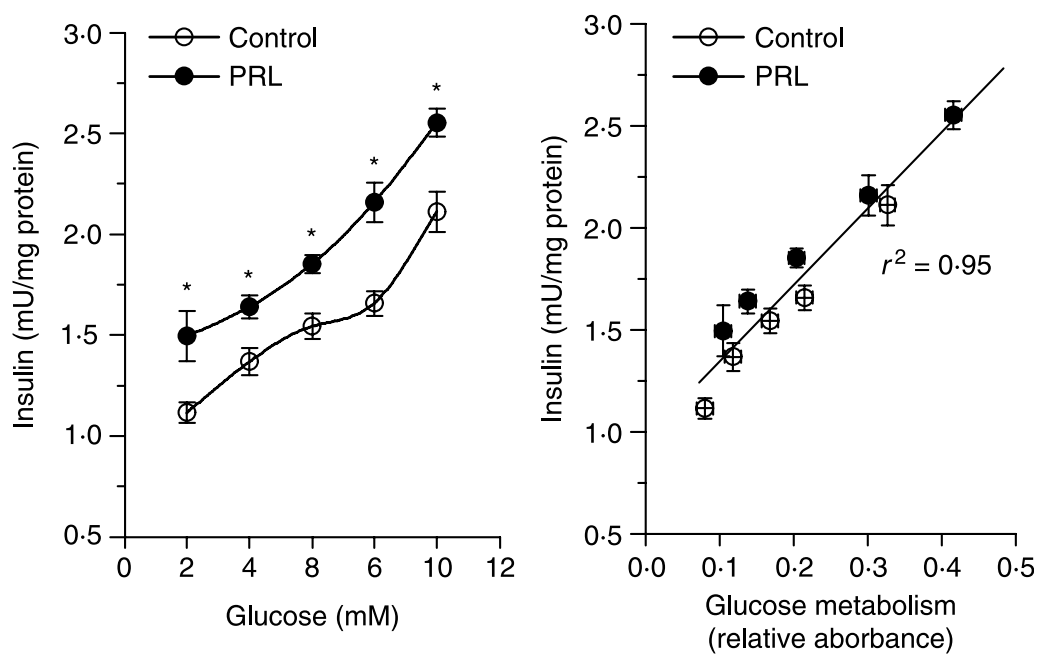

$\beta$-actin

PRL-R

Insulin

B Glucokinase

Glut-2

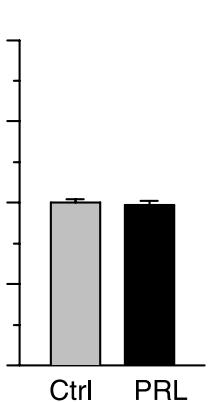

Figure $3 \mathrm{PRL}$ in the absence of glucose can enhance $\beta$-cell function in INS-1 cells. INS- 1 cells were cultured for $48 \mathrm{~h}$ in the absence of glucose. (A) When stimulated with 2-10 mM glucose for $1 \mathrm{~h}$, PRL increased glucose metabolism and insulin secretion at all glucose concentrations $\left({ }^{*} P<0 \cdot 05, n=4\right)$. There is a linear relationship $\left(r^{2}=0 \cdot 95\right)$ between glucose metabolism and insulin secretion from both control and PRL-treated INS-1 cells. (B) In the absence of glucose, PRL increased the protein levels of glucokinase, glucose transporter 2 (Glut-2), PRL receptor (PRL-r), and insulin $\left({ }^{*} P<0 \cdot 05, n=4\right)$. The similar protein levels of $\beta$-actin suggests these increases are not due to changes in total cellular proteins.

an increase in glucokinase mRNA with PRL in INS-1 cells using northern blot analysis (Petryk et al. 2000). To better detect the expected small changes in mRNA, we measured glucokinase mRNA by quantitative RT-PCR in INS-1 cells cultured for 2 days in $10 \mathrm{mM}$ glucose. In each trial, an increase in glucokinase mRNA was observed with an average increase of $26 \pm 7 \%$ (Fig. $8 \mathrm{~A}, P<0 \cdot 01$ ). PRL also increased glucokinase mRNA by a similar $24 \%$ in rat islets cultured for 2 days in $10 \mathrm{mM}$ glucose,

$P R L$ increases the synthesis of glucokinase without altering its stability

Since glucokinase activity is regulated at both transcriptional and post-translational levels in $\beta$-cells (Iynedjian 2004,
Magnuson \& Matschinsky 2004), the effect of PRL on the synthesis and stability of glucokinase was examined. INS-1 cells were cultured for $48 \mathrm{~h}$ in 0 or $10 \mathrm{mM}$ glucose before labeling with $\left[{ }^{35} \mathrm{~S}\right]$ methionine. PRL increased the synthesis of glucokinase by $73 \pm 7 \%$ after culture in the absence of glucose (Fig. 8B, $P<0 \cdot 01$ ). Culturing in $10 \mathrm{mM}$ glucose alone increased synthesis to $300 \pm 44 \%$ of the rate in the absence of glucose (Fig. 8B, $P<0 \cdot 01$ ). Even at the higher rate of synthesis, PRL induced a similar $63 \pm 13 \%$ increase after culture with $10 \mathrm{mM}$ glucose (Fig. $8 \mathrm{~B}, P<0 \cdot 01$ ). To assess the degradation rate of glucokinase, INS-1 cells were pulselabeled with $\left[{ }^{35} \mathrm{~S}\right]$ methionine for $3 \mathrm{~h}$ and then chased for an additional $24 \mathrm{~h}$. The glucokinase protein half-life was unchanged in the presence of PRL $(23.4 \mathrm{~h}$ vs $23.1 \mathrm{~h}$, Fig. 8B). 
B

A

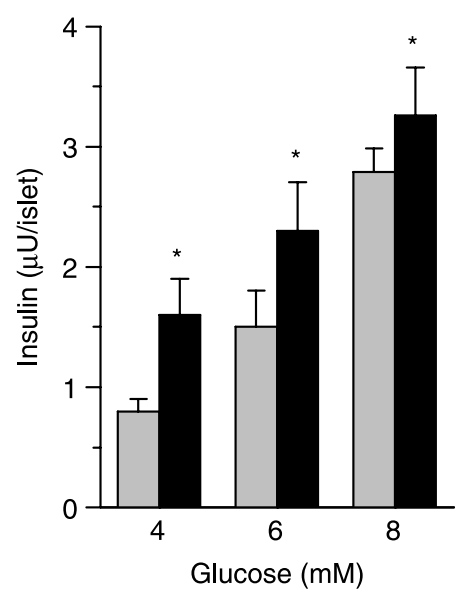

Glucokinase
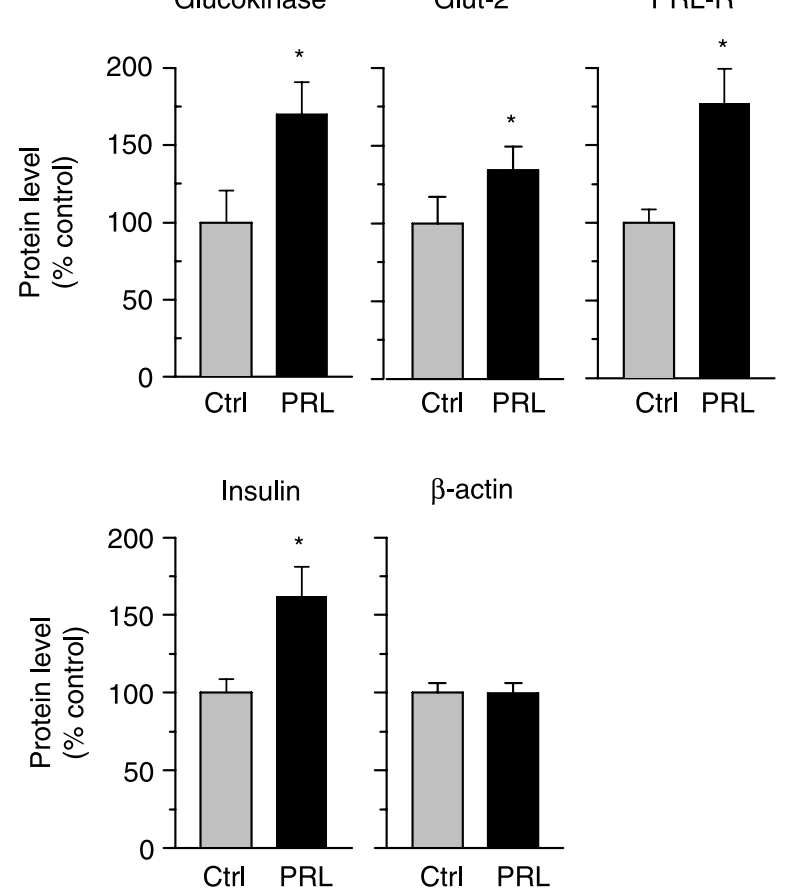

Figure $4 \mathrm{PRL}$ in the absence of glucose can enhance $\beta$-cell function in rat islets. Islets were cultured for $48 \mathrm{~h}$ in the absence of glucose. (A) When stimulated with 4-8 $\mathrm{mM}$ glucose for $1 \mathrm{~h}$, PRL increased insulin secretion at all glucose concentrations $\left({ }^{*} P<0 \cdot 05, n=4\right)$. (B) PRL increased the protein levels of glucokinase, glucose transporter 2 (Glut-2), PRL receptor (PRL-r), and insulin ( $\left.{ }^{*} P<0 \cdot 05, n=4\right)$. The similar protein levels of $\beta$-actin suggests these increases are not due to changes in total cellular proteins.

\section{Discussion}

This study examined the mechanisms used by PRL to regulate glucokinase expression and insulin secretion in $\beta$-cells. Islets cultured with PRL have increased glucokinase activity and protein levels, glucose metabolism, and insulin secretion (Weinhaus et al. 1996, 1998). Since glucose itself regulates the levels of glucokinase activity and protein levels in $\beta$-cells (Liang et al. 1992, Marie et al. 1993, Chen et al. 1994, Gasa et al. 2000), this increase in glucokinase may occur directly through STAT5 activation or indirectly as a result of other changes in glucose metabolism. A direct effect on the glucokinase transcription would be similar to other PRL responsive genes in $\beta$-cells, such as the PRL-r (Galsgaard et al. 1999), insulin (Galsgaard et al. 1996) and cyclin D2 (Friedrichsen et al. 2003).

Because of the limited information on the relationship between the effects of PRL and glucose, we examined the effects of PRL on INS-1 cells and normal islets cultured at different glucose concentrations. In both transformed and normal $\beta$-cells, culturing in increasing glucose concentrations induced corresponding increases in glucokinase expression and insulin secretion. It is unlikely that hexokinase I contributes to these effects, since PRL does not alter hexokinase I levels in islets (Weinhaus et al. 1996) which in addition fall to very low amounts in cultured islets (Liang 1990, Weinhaus et al. 1996). These results confirm that glucose is an important regulator of glucokinase expression in $\beta$-cells.

Although the effect of glucose on glucokinase was observed in both INS-1 cells and islets, the response in islets was much greater (45\% increase in INS-1 cells compared with a sevenfold increase in islets). Also PRL was less effective in enhancing glucokinase in INS-1 cells at all glucose concentrations compared with islets. PRL increased glucokinase $\sim 70 \%$ in islets cultured in 0,2 , or $4 \mathrm{mM}$ glucose. In islets cultured in glucose concentrations above the threshold for glucose stimulated insulin secretion (i.e. $5.0 \mathrm{mM}$ ), the effect of PRL was twice as large or an $\sim 140 \%$ increase in glucokinase in comparison with the control islets. This demonstrates that PRL can increase glucokinase expression in normal $\beta$-cells at glucose concentrations below the threshold for glucose-stimulated insulin secretion, including in the absence of glucose. In addition, this effect can be further enhanced by culturing the islets at stimulatory glucose concentrations. This suggests that there is a glucosedependent and a glucose-independent component to the regulation of glucokinase by PRL in normal $\beta$-cells.

Since most studies use culture media containing glucose, we further characterized the effects of PRL on $\beta$-cell function 
A

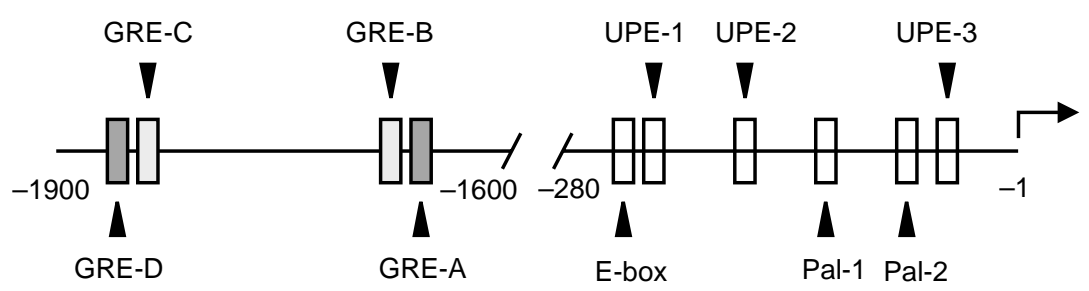

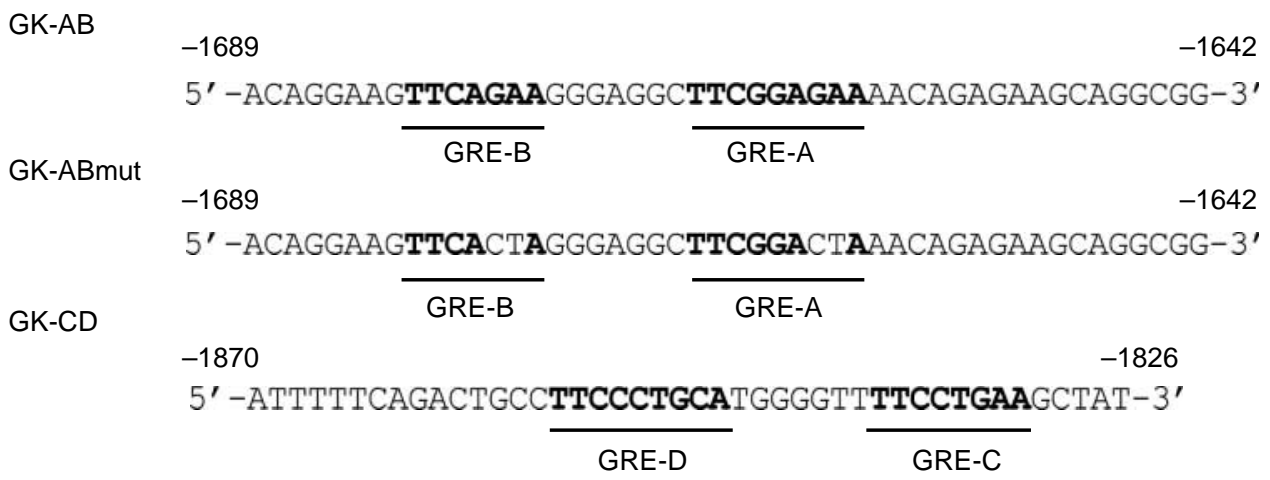

B

Western blot

Southwestern blots

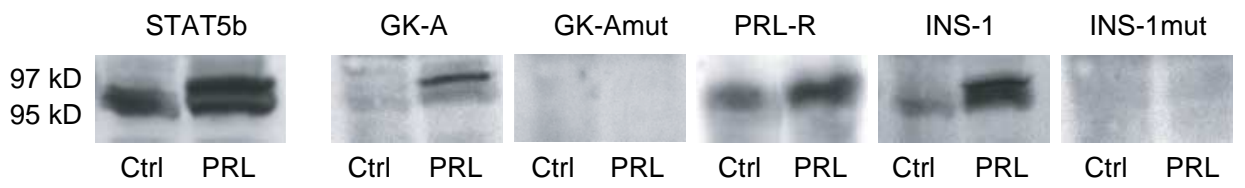

$$
\begin{array}{ll}
\text { GK-A } & \text { 5' -GGAGGCTTCGGAGAAAA-3' } \\
\text { GK-Amut } & \text { 5' -GGAGGCTTCGGCTAAAA-3' } \\
\text { PRL-R } & \text { 5' -AGCTAGTTCTAGGAATA-3' } \\
\text { INS1 } & \text { 5'-AGCTCTTTCTGGGAAAT-3' } \\
\text { INS1mut } & \text { 5'-AGCTCTTTCTGACAAAA-3' }
\end{array}
$$

Figure 5 PRL increases binding to a GAS motif from the upstream glucokinase promoter region. (A) The rat upstream glucokinase promoter contains four GAS-related elements TTCN ${ }_{m}$ GAA (labeled GRE-A thru GRE-D) from -1600 to -2000 . GRE-A and GRE-D are similar to the consensus GAS motif required for STAT5 binding with $m=3$. GRE-B with $m=1$ and GRE-C with $m=2$ are non-consensus GAS motifs that may stabilize the binding of multiple STAT5 dimers. The sequence of the tandem oligionucleotide probes GK-AB, GK-ABmut, and GK-CD are shown. (B) Western blots of nuclear extracts of INS-1 cells probed with a STAT5b antibody have bands at 95 and $97 \mathrm{kDa}$ that correspond to non- and tyrosine phosphorylated STAT5b respectively. The later was detected only with PRL treatment. Reprobing with oligonucleotide probes containing GAS motifs from the rat glucokinase (GK-A), PRL receptor (PRL-r), and insulin 1 (INS-1) promoters produced bands in the same location. No binding occurred with mutated GAS motifs from the glucokinase (GK-Amut) and insulin 1 (INS-1 mut) promoters.

in the absence of glucose. PRL was still able to increase insulin secretion with a lowering of the threshold for glucosestimulated insulin secretion in both INS-1 cells and islets. The increases in glucose metabolism were proportional to the increase in insulin secretion. This relationship is identical to that seen after culturing with PRL in $10 \mathrm{mM}$ glucose (Weinhaus et al. 1998). In addition to glucokinase, the effect of PRL on two other proteins shown to be regulated by PRL through a JAK/STAT5 mediated mechanism (Galsgaard et al. 1996, 1999) was examined. Like glucokinase, PRL treatment of islets in the absence of glucose resulted in a similar increase in PRL-r and insulin. Since glucokinase responded to PRL treatment similar to PRL-r and insulin, it suggested that it also may be regulated through a JAK/STAT mechanism. 


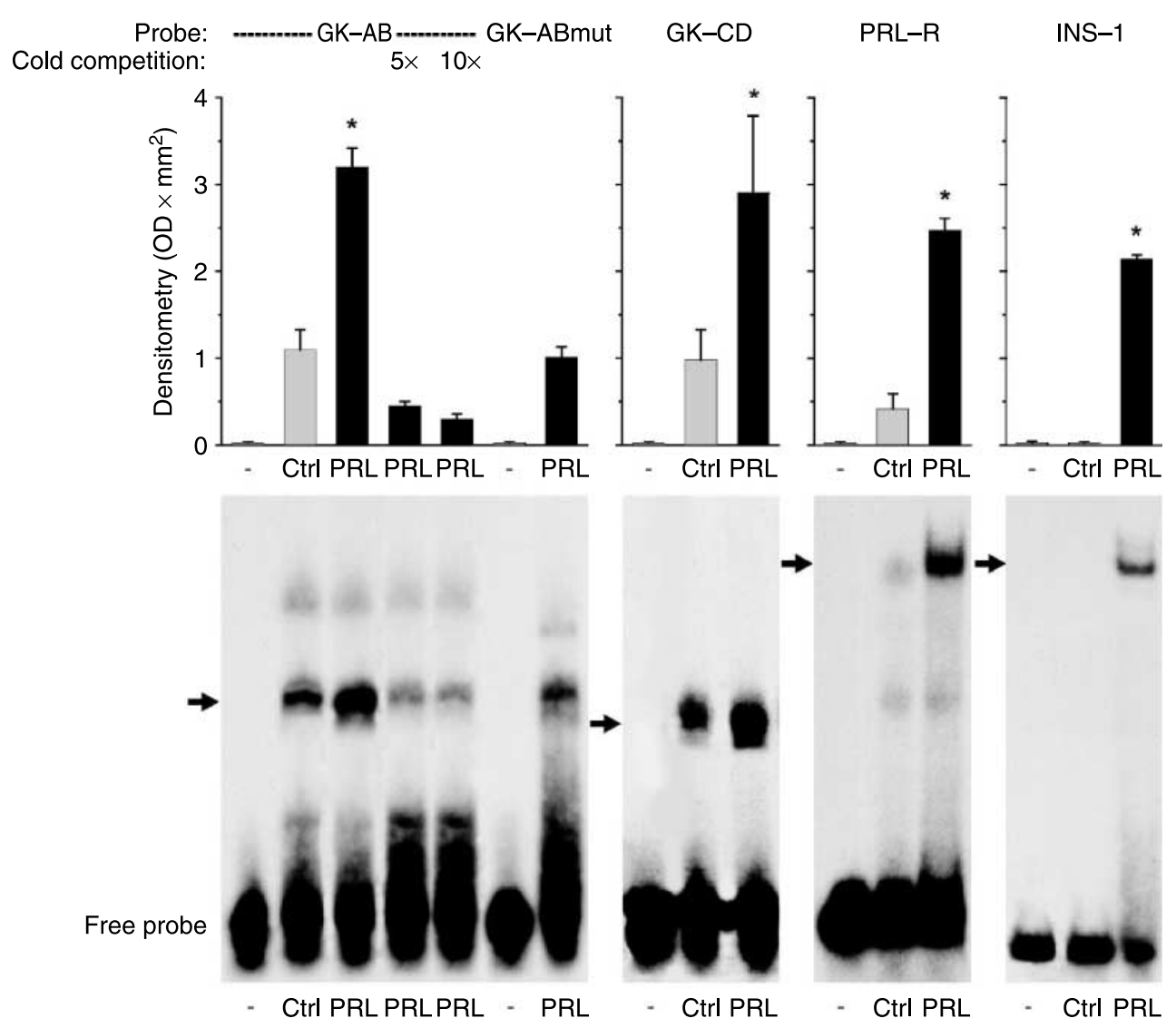

Figure 6 PRL increases binding to GAS motifs from PRL-responsive promoters. EMSA was performed with nuclear extracts from INS-1 cells and probes GK-AB and GK-CD. PRL increased binding to both GK-AB $\left({ }^{*} P<0 \cdot 001, n=7\right)$ and GK-CD $\left({ }^{*} P<0 \cdot 05, n=3\right)$. Binding was reduced by a five- or tenfold excess of unlabeled GK-AB or the mutation of the GRE sequences (GK-ABmut; $* P<0 \cdot 001, n=4)$. PRL also increased binding to GAS motifs from the rat PRL receptor (PRL-r) and insulin 1 (INS-1) promoters $\left({ }^{*} P<0 \cdot 001, n=4\right)$.

Glucokinase mRNA is produced from two distinct promoters that are utilized in a tissue-specific manner (Magnuson \& Shelton 1989). The upstream promoter controls its expression in the pancreas, duodenum, pituitary, and the brain, whereas the promoter $\sim 35 \mathrm{kB}$ downstream is used in the liver. In the liver, the expression of glucokinase is strictly dependent on the presence of insulin and is suppressed by glucagon (Iynedjian et al. 1989). The insulin receptor directly activates STAT5b in hepatocytes and may increase transcription from the hepatocyte-specific downstream glucokinase promoter through a GAS motif at -1368 to -1360 (Sawka-Verhelle et al. 2000). This region also contains several additional GAS related elements that look like potential STAT5 binding sites (Sawka-Verhelle et al. 2000). An examination of the rat upstream glucokinase promoter also revealed four GAS-related elements (GRE) located between -2000 and -1600 of transcription initiation (Fig. 5). However, only GRE-A and GRE-D match the consensus GAS motif required for binding of STAT5 (Ehret et al. 2001). Interestingly, the human upstream glucokinase promoter also contains a potential GAS motif surrounded by several GAS-related elements in the region located around -2010 .

Our results suggest these GRE motifs in the upstream glucokinase promoter may be low affinity binding sites for STAT5. Although GRE-A and GRE-D bound a protein of the same molecular weight as activated STAT5b in southwestern blots, neither formed complexes in EMSAs by themselves. Previous studies have shown that the DNA sequence of GAS motifs and their flanking regions have dramatic effects on the affinity of STAT5 binding (Ehret et al. 2001). In some cases, the transcriptional activation of several STAT5 responsive genes have been shown to require two tandemly linked GAS motifs (Verdier et al. 1998, John et al. 1999, Soldaini et al. 2000). This led us to speculate that sequences adjacent to GRE-A and GRE-D were required for higher affinity binding. Unlike the individual GREs, the two tandem probes GK-AB and GK-CD formed complexes that increased with PRL. In competition studies, binding was reduced by an excess of these unlabeled probes or one containing the GAS motif from the PRL-r promoter. This suggested that these probes are indeed competing for the same 
A
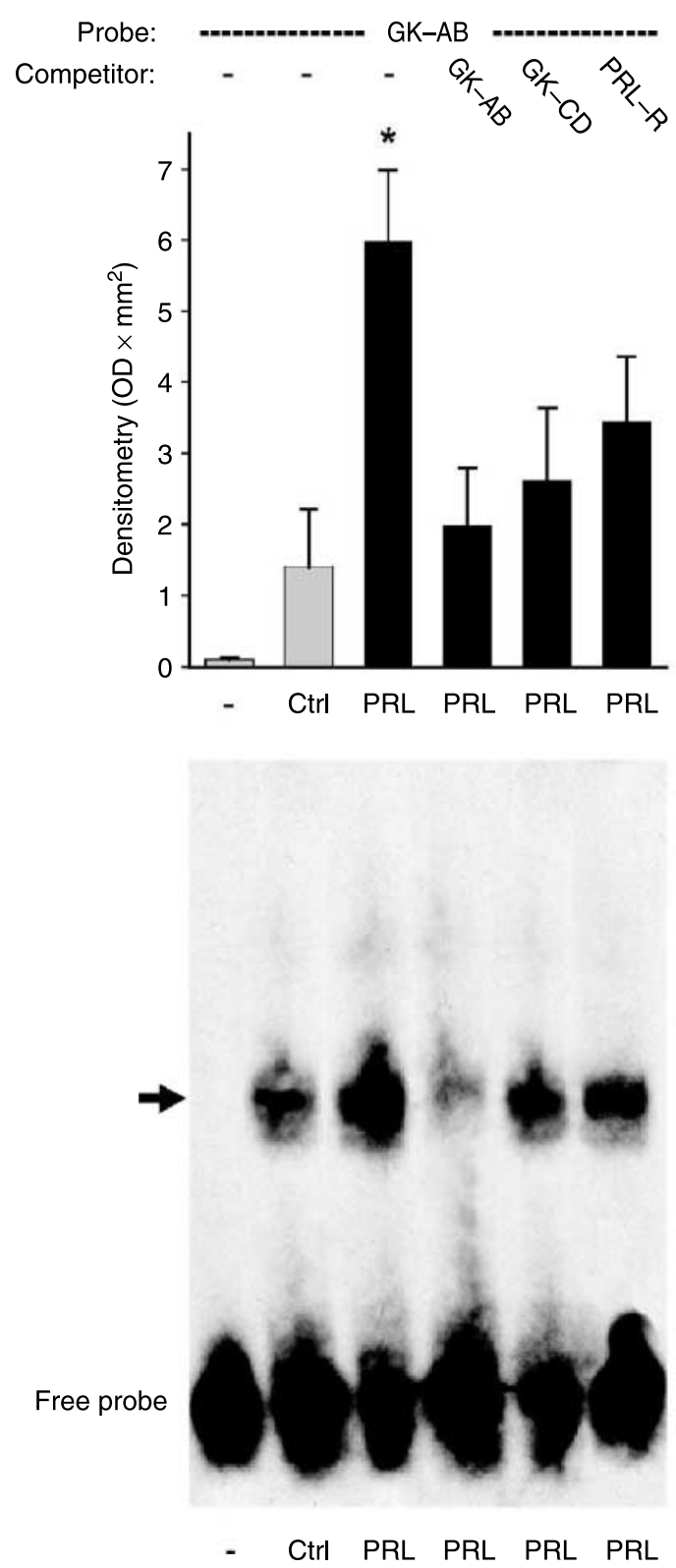

B
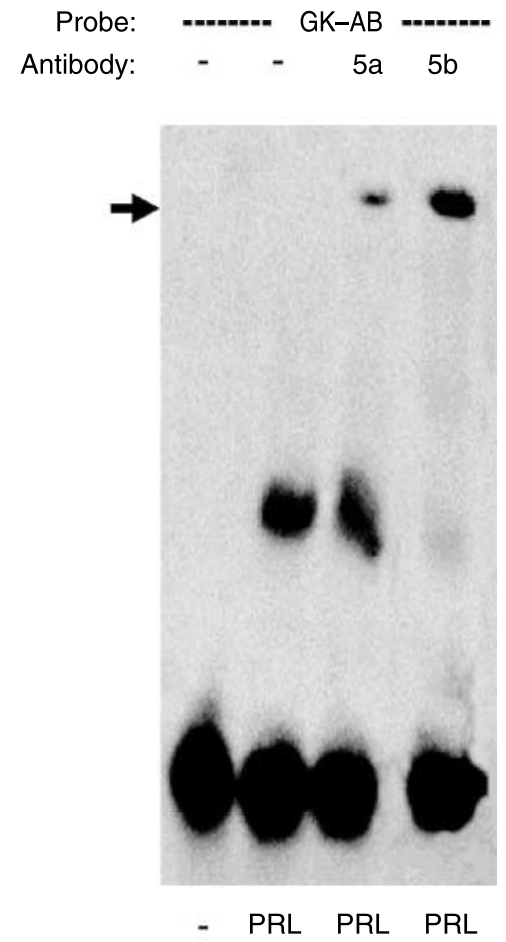

Figure 7 PRL-induced binding of STAT5 to GAS motifs from the upstream glucokinase promoter. (A) EMSA was performed with nuclear extracts from INS-1 cells and probe GK-AB. The PRL-induced binding was reduced by a tenfold excess of unlabeled GK-AB or GK-CD $\left({ }^{*} P<0 \cdot 05, n=3\right)$. Similarly, competition with the GAS motif from the PRL receptor (PRL-r) promoter suggests STAT5 is one of the bound proteins $\left({ }^{*} P<0 \cdot 05, n=3\right)$. (B) The bound complex was partly supershifted by a STAT5a (5a) antibody and almost completely supershifted by a STAT5b (5b) antibody.

protein(s). The ability to supershift this complex with STAT5 antibodies demonstrates that STAT5a and STAT5b are involved. The partial supershift with an anti-STAT5a antibody and almost completely supershift by an antiSTAT5b antibody is similar to the GAS motif from the
PRL-r promoter. This may reflect a higher level of STAT5b expression relative to STAT5a as seen in INS-1 cells (Galsgaard et al. 1999) or it could reflect differences in the binding affinities of the GAS motifs and their flanking sequences. 
A

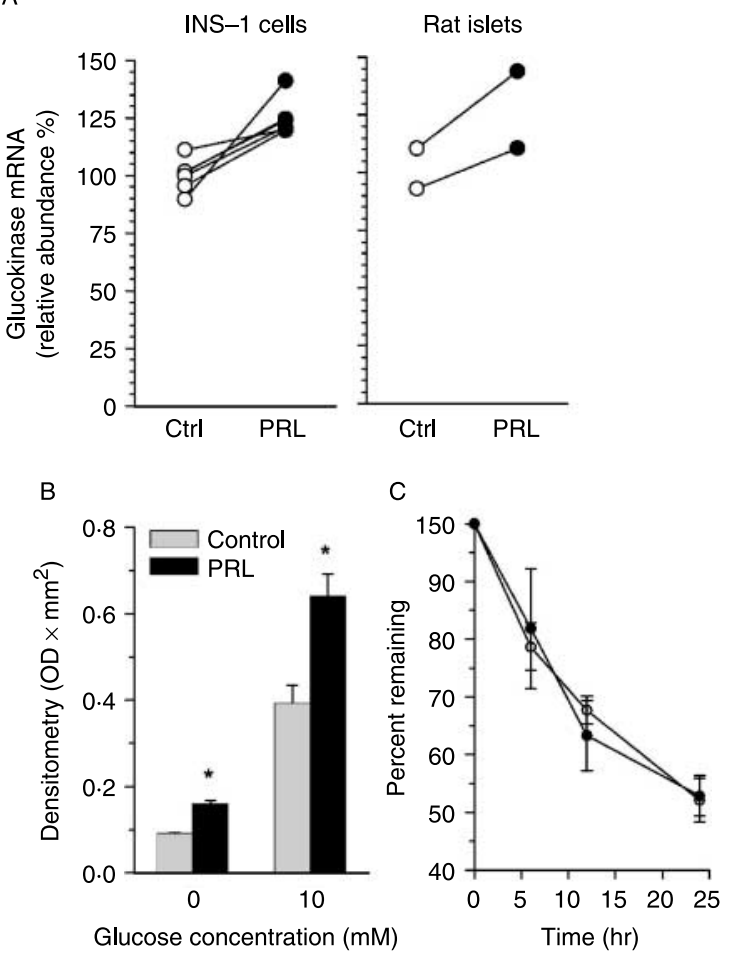

Figure 8 PRL increases glucokinase mRNA and synthesis. INS-1 cells and islets were cultured for $48 \mathrm{~h}$ in $10 \mathrm{mM}$ glucose. (A) Glucokinase mRNA was measured and the paired values for individual experiments are shown. PRL increased glucokinase mRNA in both INS-1 cells $(P<0 \cdot 01, n=6)$ and rat islets $(n=2)$. (B) PRL increased glucokinase synthesis measured in INS-1 cells by pulse-labeling with ${ }^{35}$ S] methionine for $10 \mathrm{~min}$ at both 0 and $10 \mathrm{mM}$ glucose $(* P<0 \cdot 01, n=6)$. (C) Degradation after pulselabeling with $\left.{ }^{35} \mathrm{~S}\right]$ methionine for $3 \mathrm{~h}$ at $10 \mathrm{mM}$ glucose showed the half-life of glucokinase was unchanged by PRL $(n=3)$.

Although the results of this study support the hypothesis that PRL regulates glucokinase transcription directly by way of STAT5 binding to its promoter it does not preclude that indirect effects of STAT5 activation may also influence gene transcription. STAT5 could function as a cofactor for other transcription factors or induce the expression of other transacting factors. For example, PRL increases PDX-1 levels and expression from reporter constructs containing the rat PDX-1 promoter in INS-1 cells even though it does not contain identified STAT5 binding sites (Nasir et al. 2005). Since the promoters of several PRL responsive genes contain PDX-1 binding sites (McKinnon \& Docherty 2001), it may contribute along with STAT5 activation to the increased transcription of these genes. Also, although insulin expression has been shown to be regulated by PRL through a STAT5 mechanism, there is evidence that PRL may also regulate insulin transcription through a mechanism not involving STAT5 (Fleenor \& Freemark 2001). It is also possible that the enhanced insulin secretion observed with PRL treatment may feed back on $\beta$-cells to also contribute to the regulation of glucokinase. It will require extensive additional experiments to determine to what extent these other less direct pathways contribute to the regulation of glucokinase.

Further support for the hypothesis that PRL regulates the transcription of the glucokinase gene in $\beta$-cells comes from the observation that PRL induced a $25 \%$ increase in glucokinase mRNA in both INS-1 cells and rat islets. This differs from a previous study, which failed to detect an effect of PRL on glucokinase mRNA in INS-1-cells (Petryk et al. 2000), but agrees with a report which showed an increase in glucokinase mRNA in adult rat islets with PRL (Bordin et al. 2004). The experiments measuring the rates of glucokinase biosynthesis and degradation further supports the proposal that PRL can regulate glucokinase transcription. Similar to its effects on the protein levels of glucokinase, changing from 0 to $10 \mathrm{mM}$ glucose during culture increased the rate of glucokinase synthesis by $300 \%$. This difference reflects changes in translation because glucose has no effect on glucokinase mRNA in INS-1 cells (Marie et al. 1993). More importantly, PRL further increased glucokinase synthesis by 60 to $70 \%$ in either the absence or presence of $10 \mathrm{mM}$ glucose. This would be expected if PRL increased glucokinase mRNA through a glucose-independent mechanism. The absence of changes in the protein stability of glucokinase with PRL suggests post-translational mechanisms are not involved. Overall, the PRL-induced increase in glucokinase mRNA and its translation are sufficient to account for the elevated glucokinase expression.

The regulation of glucokinase expression by lactogens may have physiological implications beyond pregnancy. Glucokinase has an essential role in glucose-stimulated insulin secretion from $\beta$-cells by determining the rate of metabolism in response to changes in plasma glucose (Matschinsky et al. 1993). Small changes in glucokinase activity have large effects on glucose-stimulated insulin secretion, as indicated by studies with humans with maturity onset diabetes of young, type 2 (Davis et al. 1999) and tissue-specific gene knock-out mice (Postic et al. 1999). The presence of PRL and growth hormone receptors on $\beta$-cells suggest both hormones may be involved in the regulation of islet function (Brelje et al. 2004). Insulin secretion is reduced in conditions of both growth hormone deficiency (Parsons et al. 1995) and in PRL-r deficient mice (Freemark et al. 2002). These observations suggest that the maintenance of normal glucose sensitivity of $\beta$-cells requires the presence of both PRL and growth hormone. Moreover, hyperprolactinemia in humans is associated with an exaggerated secretory response to glucose and a lowering of the threshold for stimulation (Landgraf et al. 1977, Gustafson et al. 1980). A recent study also demonstrated that transgenic mice expressing a dominant-negative mutant STAT5 or constitutive active mutant STAT5 in $\beta$-cells influences their susceptibility to experimentally induced type 1 and 2 diabetes (Jackerott et al. 2006). The regulation of glucokinase levels by STAT 5 may contribute to the changes in glucose sensitivity observed with these conditions. 


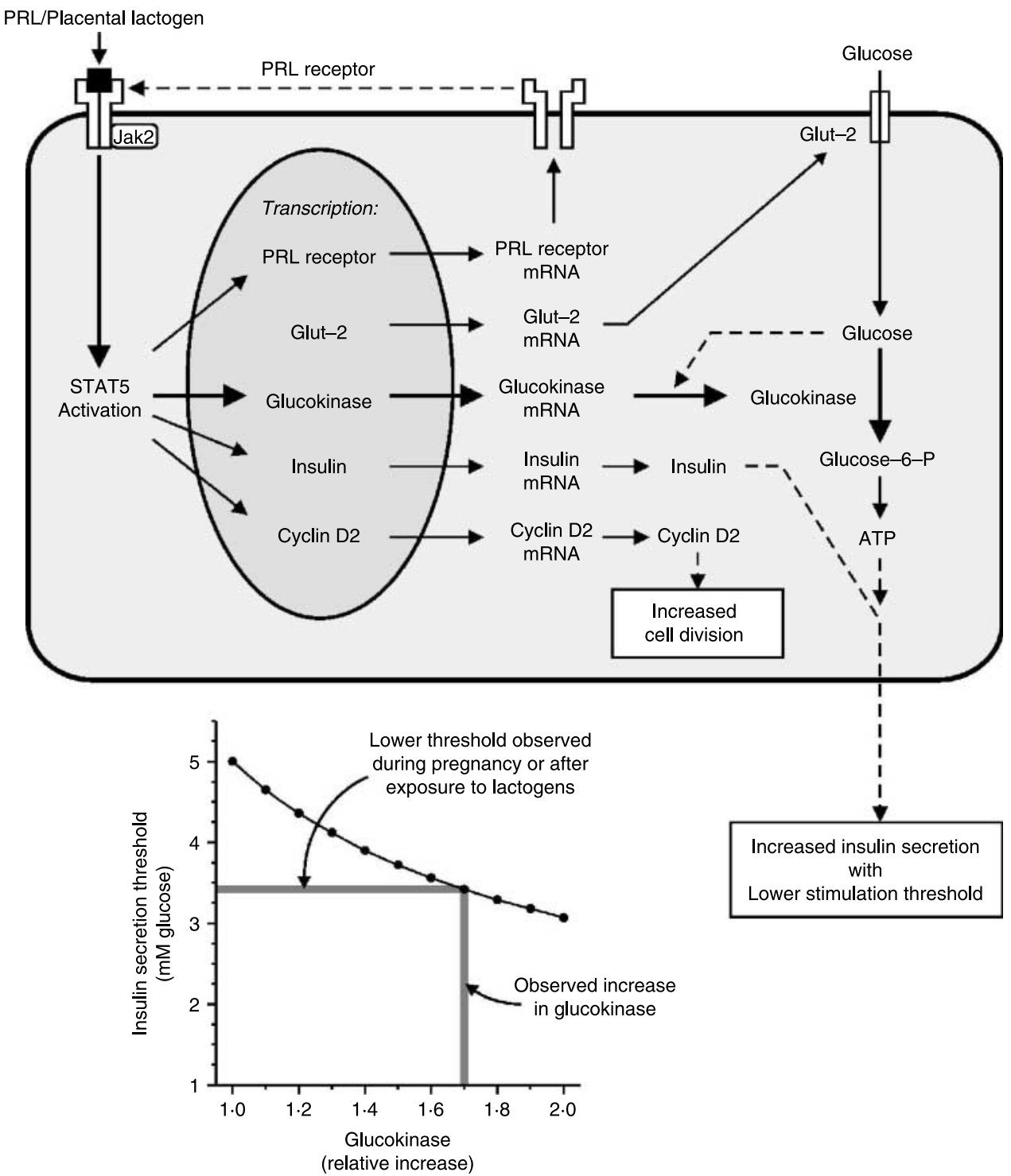

Figure 9 A model of the mechanisms by which islets adapt during pregnancy. Lactogens, either PRL or placental lactogen, bind to PRL receptors on $\beta$-cells and activates the JAK/STAT signaling pathway. Activated STAT5 binds to GAS motifs in the promoters of target genes and increases their transcription. An increase in the prolactin receptor is needed to maintain the prolonged activation of STAT5 by lactogens in $\beta$-cells (Brelje et al. 2004). The elevation in glucokinase increases glucose metabolism, lowers the threshold for glucose stimulation, and enhances insulin secretion. This occurs through a glucose-independent mechanism, most likely a STAT5b-mediated increase in glucokinase transcription, and at high glucose concentrations an additional glucose-dependent mechanism involving changes at translational or protein stability levels. The graph is derived from a mathematical model for the effect of changes in glucokinase levels on the threshold of glucose-stimulated insulin secretion developed by Davis et al. (1999). The 1.7-fold increase in glucokinase activity with PRL in islets at normal serum glucose levels (Fig. 2) would be expected to reduce the threshold of glucose-stimulated insulin secretion to 3.3 to $3.5 \mathrm{mM}$. This matches the observed threshold of $3.3 \mathrm{mM}$ glucose during pregnancy or after exposure to lactogens (Sorenson \& Parsons 1985, Brelje \& Sorenson 1988, Parsons et al. 1992). Similarly, the increased demand for insulin is met through an increase in the transcription and synthesis of insulin (Galsgaard et al. 1996). The stimulation of $\beta$-cell proliferation by lactogens involves an increase in cyclin D2 expression (Friedrichsen et al. 2003). 
The results from our experiments further our understanding of how islets adapt during pregnancy to meet the increased demand for insulin. These changes occur under the influence of lactogenic hormones at normal blood glucose conditions. The most significant outcomes are an increase in insulin secretion with a lowering of the threshold for glucose stimulation and an increase in islet mass. These are two quite diverse cellular processes, one which is highly differentiated (insulin secretion) and one which is common to many cells (mitosis). Binding of PRL or placental lactogen to PRL-r on $\beta$-cells leads to activation of the JAK/STAT5 signaling pathway and an increase in the transcription of several genes required for the up-regulation of islet function (Fig. 9). Central to this adaptation is an increase in glucokinase activity that results in enhanced glucose metabolism. This increase in glucose metabolism is responsible for lowering the threshold of glucose-stimulated insulin secretion. The $70 \%$ increase in glucokinase activity observed in our experiments would be expected to reduce the threshold of glucose-stimulated insulin secretion from 5.5 to $3.3 \mathrm{mM}$ based on a model for glucose-stimulated insulin secretion developed by Davis et al. (1999) Fig. 9. This matches the observed threshold of $3.3 \mathrm{mM}$ glucose during pregnancy or after exposure to lactogens (Sorenson \& Parsons 1985, Brelje \& Sorenson 1988, Parsons et al. 1992). An increase in the expression of the cell cycle regulator cyclin D2 should lead to an increase in $\beta$-cell proliferation (Friedrichsen et al. 2003). Although an increase in islet mass contributes to enhanced insulin secretion, it is only by the lowering of the threshold through increased glucokinase activity that islets can secrete large amounts of insulin without the need for prolonged hyperglycemia (Parsons et al. 1992).

In summary, these experiments demonstrate that PRL can increase glucokinase expression through a glucose-independent mechanism in $\beta$-cells. This most likely occurs through the activation of the JAK2/STAT5 pathway by the PRL-r. The presence of STAT5b binding sites in the upstream glucokinase promoter, an increase in glucokinase mRNA, and an elevation of glucokinase biosynthesis support this hypothesis. A better understanding of the regulation of glucokinase levels by activation of STAT5 may have potential applications of improving the glucose sensitivity of $\beta$-cells.

\section{Acknowledgements}

This research was supported by NIH grant DK33655. We would like to thank Dr AF Parlow from the National Hormone and Pituitary Program of the NIDDK for providing the rat PRL used in this study. We also would like to thank Ms Rebecca Assuma for her excellent technical assistance. The authors declare that there is no conflict of interest that would prejudice the impartiality of this scientific work.

\section{References}

Bordin S, Amaral ME, Anhe GF, Delghingaro-Augusto V, Cunha DA, Nicoletti-Carvalho JE \& Boschero AC 2004 Prolactin-modulated gene expression profiles in pancreatic islets from adult female rats. Molecular and Cellular Endocrinology 220 41-50.

Brelje TC \& Sorenson RL 1988 Nutrient and hormonal regulation of the threshold of glucose-stimulated insulin secretion in isolated rat pancreases. Endocrinology 123 1582-1590.

Brelje TC, Scharp DW, Lacy PE, Ogren L, Talamantes F, Robertson M, Friesen HG \& Sorenson RL 1993 Effect of homologous placental lactogens, prolactins, and growth hormones on islet B-cell division and insulin secretion in rat, mouse, and human islets: implication for placental lactogen regulation of islet function during pregnancy. Endocrinology 132 879-887.

Brelje TC, Svensson AM, Stout LE, Bhagroo NV \& Sorenson RL 2002 An immunohistochemical approach to monitor the prolactin-induced activation of the JAK2/STAT5 pathway in pancreatic islets of Langerhans. Journal of Histochemistry and Cytochemistry 50 365-383.

Brelje TC, Stout LE, Bhagroo NV \& Sorenson RL 2004 Distinctive roles for prolactin and growth hormone in the activation of signal transducer and activator of transcription 5 in pancreatic islets of langerhans. Endocrinology 145 4162-4175.

Chen C, Hosokawa H, Bumbalo LM \& Leahy JL 1994 Regulatory effects of glucose on the catalytic activity and cellular content of glucokinase in the pancreatic beta cell. Study using cultured rat islets. Journal of Clinical Investigation 94 1616-1620.

Davis EA, Cuesta-Munoz A, Raoul M, Buettger C, Sweet I, Moates M, Magnuson MA \& Matschinsky FM 1999 Mutants of glucokinase cause hypoglycaemia- and hyperglycaemia syndromes and their analysis illuminates fundamental quantitative concepts of glucose homeostasis. Diabetologia 42 1175-1186.

Ehret GB, Reichenbach P, Schindler U, Horvath CM, Fritz S, Nabholz M \& Bucher P 2001 DNA binding specificity of different STAT proteins. Comparison of in vitro specificity with natural target sites. Journal of Biological Chemistry 276 6675-6688.

Fernandez-Mejia C, Vega-Allende J, Rojas-Ochoa A, Rodriguez-Dorantes M, Romero-Navarro G, Matschinsky FM, Wang J \& German MS 2001 Cyclic adenosine $3^{\prime}, 5^{\prime}$-monophosphate increases pancreatic glucokinase activity and gene expression. Endocrinology 142 1448-1452.

Fleenor DE \& Freemark M 2001 Prolactin induction of insulin gene transcription: roles of glucose and signal transducer and activator of transcription 5. Endocrinology 142 2805-2810.

Freemark M, Avril I, Fleenor D, Driscoll P, Petro A, Opara E, Kendall W, Oden J, Bridges S, Binart N et al. 2002 Targeted deletion of the PRL receptor: effects on islet development, insulin production, and glucose tolerance. Endocrinology 143 1378-1385.

Friedrichsen BN, Galsgaard ED, Nielsen JH \& Moldrup A 2001 Growth hormone- and prolactin-induced proliferation of insulinoma cells, INS-1, depends on activation of STAT5 (signal transducer and activator of transcription 5). Molecular Endocrinology 15 136-148.

Friedrichsen BN, Richter HE, Hansen JA, Rhodes CJ, Nielsen JH, Billestrup N \& Moldrup A 2003 Signal transducer and activator of transcription 5 activation is sufficient to drive transcriptional induction of cyclin D2 gene and proliferation of rat pancreatic beta-cells. Molecular Endocrinology 17 945-958.

Galsgaard ED, Gouilleux F, Groner B, Serup P, Nielsen JH \& Billestrup N 1996 Identification of a growth hormone-responsive Stat5-binding element in the rat insulin 1 gene. Molecular Endocrinology 10 652-660.

Galsgaard ED, Nielsen JH \& Moldrup A 1999 Regulation of prolactin receptor $(P R L R)$ gene expression in insulin- producing cells. Prolactin and growth hormone activate one of the rat prlr gene promoters via STAT5a and STAT5b. Journal of Biological Chemistry 274 18686-18692.

Gasa R, Fabregat ME \& Gomis R 2000 The role of glucose and its metabolism in the regulation of glucokinase expression in isolated human pancreatic islets. Biochemical and Biophysical Research Communications 268 491-495. 
Gremlich S, Bonny C, Waeber G \& Thorens B 1997 Fatty acids decrease IDX-1 expression in rat pancreatic islets and reduce Glut2, glucokinase, insulin, and somatostatin levels. Journal of Biological Chemistry 272 30261-30269.

Gustafson AB, Banasiak MF, Kalkhoff RK, Hagen TC \& Kim HJ 1980 Corrleation of hyperprolactinemia with altered plasma insulin and glucagon: similarity to effects of late human pregnancy. Journal of Clinical Endocrinology and Metabolism 51 242-246.

Hegre OD, Marshall S, Schulte BA, Hickey GE, Williams F, Sorenson RL \& Serie JR 1983 Nonenzymic in vitro isolation of perinatal islets of Langerhans. In Vitro 19 611-620.

Ihle JN 1996 STATs: signal transducers and activators of transcription. Cell 84 331-334.

Iynedjian PB 2004 Molecular biology of glucokinase regulation. Frontiers in Diabetes 16 155-168.

Iynedjian PB, Jotterand D, Nouspikel T, Asfari M \& Pilot PR 1989 Transcriptional induction of glucokinase gene by insulin in cultured liver cells and its repression by the glucagon-cAMP system. Journal of Biological Chemistry 264 21824-21829.

Jackerott M, Moldrup A, Thams P, Galsgaard ED, Knudsen J, Lee YC \& Nielsen JH 2006 STAT5 activity in pancreatic \{beta\}-cells influences the severity of diabetes in animal models of Type 1 and 2 diabetes. Diabetes $\mathbf{5 5}$ 2705-2712.

John S, Vinkemeier U, Soldaini E, Darnell JE \& Leonard WJ 1999 The significance of tetramerization in promoter recruitment by Stat5. Molecular and Cellular Biology 19 1910-1918.

Landgraf R, Landgraf-Leurs MMC, Weissmann A, Hörl R, von Werder K \& Scriba PC 1977 Prolactin: a diabetogenic hormone. Diabetologiz 13 99-104.

Liang Y, Najafi H \& Matschinsky FM 1990 Glucose regulates glucokinase activity in cultured islets from rat pancreas. Journal of Biological Chemistry $\mathbf{2 6 5}$ 16863-16866.

Liang Y, Najafi H, Smith RM, Zimmerman EC, Magnuson MA, Tal M \& Matschinsky FM 1992 Concordant glucose induction of glucokinase, glucose usage, and glucose-stimulated insulin release in pancreatic islets maintained in organ culture. Diabetes 41 792-806.

Magnuson MA \& Matschinsky F 2004 Glucokinase as a glucose sensor: past, present and future. Frontiers in Diabetes 16 1-17.

Magnuson MA \& Shelton KD 1989 An alternate promoter in the glucokinase gene is active in the pancreatic beta cell. Journal of Biological Chemistry 264 15936-15942.

Marie S, Diaz-Guerra MJ, Miquerol L, Kahn A \& Iynedjian PB 1993 The pyruvate kinase gene as a model for studies of glucose-dependent regulation of gene expression in the endocrine pancreatic beta-cell type. Journal of Biological Chemistry 268 23881-23890.

Matschinsky F, Liang Y, Kesavan P, Wang L, Froguel P, Velho G, Cohen D, Permutt MA, Tanizawa Y, Jetton TL et al. 1993 Glucokinase as pancreatic beta cell glucose sensor and diabetes gene. Journal of Clinical Investigation 92 2092-2098.

McKinnon CM \& Docherty K 2001 Pancreatic duodenal homeobox-1, PDX-1, a major regulator of beta cell identity and function. Diabetologia 44 1203-1214.

Nasir I, Kedees MH, Ehrlich ME \& Teitelman G 2005 The role of pregnancy hormones in the regulation of Pdx-1 expression. Molecular and Cellular Endocrinology 233 1-13.

Parsons JA, Brelje TC \& Sorenson RL 1992 Adaptation of islets of Langerhans to pregnancy: increased islet cell proliferation and insulin secretion correlates with the onset of placental lactogen secretion. Endocrinology 130 1459-1466.

Parsons JA, Bartke A \& Sorenson RL 1995 Number and size of islets of Langerhans in pregnant, human growth hormone-expressing transgenic, and pituitary dwarf mice: effect of lactogenic hormones. Endocrinology 136 2013-2021.
Petryk A, Fleenor D, Driscoll P \& Freemark M 2000 Prolactin induction of insulin gene expression: the roles of glucose and glucose transporter-2. Journal of Endocrinology 164 277-286.

Postic C, Shiota M, Niswender KD, Jetton TL, Chen Y, Moates JM, Shelton KD, Lindner J, Cherrington AD \& Magnuson MA 1999 Dual roles for glucokinase in glucose homeostasis as determined by liver and pancreatic beta cell-specific gene knock-outs using Cre recombinase. Journal of Biological Chemistry 274 305-315.

Sawka-Verhelle D, Tartare-Deckert S, Decaux JF, Girard J \& Van Obberghen E 2000 Stat 5B, activated by insulin in a Jak-independent fashion, plays a role in glucokinase gene transcription. Endocrinology 141 1977-1988.

Segu VB, Li G \& Metz SA 1998 Use of a soluble tetrazolium compound to assay metabolic activation of intact beta cells. Metabolism 47 824-830.

Shao J, Qiao L \& Friedman JE 2004 Prolactin, progesterone, and dexamethasone coordinately and adversely regulate glucokinase and cAMP/PDE cascades in MIN6 beta-cells. American Journal of Physiology, Endocrinology and Metabolism 286 E304-E310.

Soldaini E, John S, Moro S, Bollenbacher J, Schindler U \& Leonard WJ 2000 DNA binding site selection of dimeric and tetrameric Stat 5 proteins reveals a large repertoire of divergent tetrameric Stat5a binding sites. Molecular and Cellular Biology 20 389-401.

Sorenson RL \& Brelje TC 1997 Adaptation of islets of Langerhans to pregnancy: beta-cell growth, enhanced insulin secretion and the role of lactogenic hormones. Hormone and Metabolic Research 29 301-307.

Sorenson RL \& Brelje TC 2001 Differences in the regulation of pancreatic islets by prolactin, growth hormone and placental lactogen. In Prolactin, pp 297-316. Ed. N Horseman. Boston: Kluwer.

Sorenson RL \& Parsons JA 1985 Insulin secretion in mammosomatotropic tumor-bearing and pregnant rats. A role for lactogens. Diabetes 34 337-341.

Sorenson RL \& Stout LE 1995 Prolactin receptors and JAK2 in islets of Langerhans: an immunohistochemical analysis. Endocrinology 136 4092-4098.

Stout LE, Svensson AM \& Sorenson RL 1997 Prolactin regulation of isletderived INS-1 cells: characteristics and immunocytochemical analysis of STAT5 translocation. Endocrinology 138 1592-1603.

Verdier F, Rabionet R, Gouilleux F, Beisenherz-Huss C, Varlet P, Muller O, Mayeux P, Lacombe C, Gisselbrecht S \& Chretien S 1998 A sequence of the CIS gene promoter interacts preferentially with two associated STAT5A dimers: a distinct biochemical difference between STAT5A and STAT5B. Molecular and Cellular Biology 18 5852-5860.

Wang H \& Iynedjian PB 1997 Modulation of glucose responsiveness of insulinoma beta-cells by graded overexpression of glucokinase. PNAS 94 4372-4377.

Weinhaus AJ, Stout LE \& Sorenson RL 1996 Glucokinase, hexokinase, glucose transporter 2, and glucose metabolism in islets during pregnancy and prolactin-treated islets in vitro: mechanisms for long term up-regulation of islets. Endocrinology 137 1640-1649.

Weinhaus AJ, Bhagroo NV, Brelje TC \& Sorenson RL 1998 Role of cAMP in upregulation of insulin secretion during the adaptation of islets of Langerhans to pregnancy. Diabetes 47 1426-1435.

Received in final form 22 March 2007

Accepted 23 March 2007

Made available online as an Accepted Preprint 27 March 2007 